\title{
Image spaces. Digital visual media in the context of baroque mural painting in architecture
}

\author{
PIOTR P. DROZDOWICZ \\ Faculty of Architecture \\ Poznan University of Technology, Poland
}

\begin{abstract}
Drozdowicz Piotr P., Image spaces. Digital visual media in the context of baroque mural painting in architecture. "Images" vol. XXIX, no. 38. Poznań 2021. Adam Mickiewicz University Press. Pp. 249-254. ISSN 1731-450X. DOI 10.14746/i.2021.38.15.

In the art of the $20^{\text {th }}$ century, space became the basic material. Today, digital media and VR and AR technologies are used to cross the visual and space barriers, but always at the expense of experiencing reality. The spatial turn in culture results from the post-avant-garde ideas of art that cuts itself off from ancient art. Using the example of the fresco by Andrea del Pozzo from the Sant'Ignazio church in Rome, we will show analogies between baroque illusionist painting and digital visual media. It turns out that contemporary art arrives at the space issues that have been practiced in architecture and art since antiquity. The space created by painting illusion as a total work of art exhibits many features of contemporary art and the phenomena of VR and AR such as intermediality, immersion, interactivity. Spatial turn arguments can be used to enhance the potential of classic painting language in architecture.
\end{abstract}

KEYWORDS: space, image, spatial turn, baroque painting, mural painting, illusion, immersion, reality, virtual reality, augmented reality

\section{The digital iconosphere}

Are analogies possible between modern digital spatial projections of virtual reality (VR), augmented reality (AR),[1] multimedia art and illusionist baroque painting? After all, space is their common denominator. How can space be depicted? Is it possible to photograph the spatial effects of the illusion of a baroque fresco, save it in a pixel frame and reproduce it? The juxtaposition of two distant artistic phenomena and conventions provokes reflection on the function of space in art and architecture. The author's many years of experience in the design and implementation of mural painting in architectural space and the interest in space in painting are the motivation to analyse the phenomenon of classical mural painting in the context of the contemporary visual arts.

It is not difficult to notice that the popularity of multimedia sound-and-light shows and light festivals, which rely on three-dimensional shows on the facades of architectural objects, is increasing around the world, as well as in Po- land. [2] Starting with the ground-breaking public projection show on $3 \mathrm{D}$ objects at Disneyland in The Haunted Mansion in 1969, projection mapping, video mapping and spatial augmented reality performances have been permanently appearing in the programs of sound-and-light festivals and concerts. [3] The technology of digital image processing and projection supported by advanced computer programs ensures perfect

[1] In the article, the abbreviations VR and AR will be used to identify both phenomena.

[2] It is worth recalling the 2008 Warrener show carried out on the facade of the Gothic cathedral of St. John the Baptist in Lyon as a part of the Fête des lumières festival.

[3] The Festival Fête des lumières, in which 2-3 million people participate every year. The genesis is religious events of 1852 associated with the dedication of the figure of the Mother of God at the Basilica of Fourvière. The largest festival of light in Poland is the festival of kinetic art of light - Light.Move.Festival - organized since 2011, <https://piklodz.pl/festiwal/festiwal-swiatla-w-lodzi>, accessed: 30.11.2019. 
media synchronization, all in order to provide the most intense visual experience. Originally analogue and then digital image projections migrate to the public space of the city from a flat, pixel screen, supported by sound effects. Architectural space becomes a medium for an image that completely embraces the recipient and strives for maximum visual experience.

Initially, static photographic image was used in stereoscopy and diaporamas, and then it evolved into $3 \mathrm{D}$ cinema through film. The projections were stationary in front of the viewer's eyes, maintaining the proscenium zone; they remained in the appropriate spatial distance, which left the viewer the freedom to turn around and leave. In VR/AR projections, the image is emancipated, beginning to live its own life; stimulated by computers, a man is surrounded by a totalitarian iconosphere, which leaves less and less freedom. The phenomenon of digital image spatialisation is a direct consequence of the changes in the function of space in fine arts in the beginning of the 2oth century.

\section{Spatial turn in art and visual media}

In the $2 \mathrm{O}^{\text {th }}$ century, there were clear turns and ideological redefinitions in culture. Just as in the philosophy of the 1960 s there was a linguistic turn, so in art and architecture the so-called spatial turn took place. It radiates to academic fields relating to space, as well as to all modern humanities. Discussion on the nature of space and its imaging methods oscillates between the theoretical attitude and the sensual approach of space experience (T. Adorno, M. Heidegger, P. M. Foucault, and many architects, e.g. J. Pallasmaa and S.E. Rasmussen).[4] Departure from a flat image in favour of space took place gradually. This is particularly evident in painting. The cubist method and abstraction-

[4] More to be found on that in G. Światek, Gry sztuki $z$ architektura, Toruń 2013, pp. 77-90.

[5] M. Foucault, O innych przestrzeniach. Heterotopie, transl. M. Żakowski, „Kultura Popularna” 2006, no. 2 (16), pp. 7-8.

[6] The subchapter consists of selected fragments of an unpublished doctoral disserta- ism were different manifestations of the decomposition of the mimesis principle in painting. The avant-garde undermined and gradually negated the visual representation of the common visual experience, which destroyed the grammar of the traditional painting language. Since Marcel Duchamp, the image has been emancipated from its physical medium and released into space. This process is commonly understood as transcending traditional imaging and struggling with a two-dimensional, captivating image plane. Phenomena such as ready-made objects, environment art, happening, performance and installation have appeared. Tadeusz Kantor, with his series of paintings with umbrellas, was a Polish artist in whose works one can trace the process of abandoning the image plane in favour of three-dimensionality of an art object. Modern art, through the actions of Dadaists or the Fluxus movement, has placed an emphasis on staging, performative actions and interactive activity in social space. The spatial turn resulted in an exclusive mentality negating en bloc traditionally understood painting, instead intensively promoting all artistic activities related to space.

Foucault, who in 1967 predicted the arrival of the age of space, thought that space issues were nothing new and that it was impossible to bypass the damaging intersection of time and space.[5] The arguments of the modern spatial turn can be used to reflect on the spatial phenomenon and visuality of classical mural painting in architecture. Let us cross time and space, which Foucault feared, by enhancing this form of painting. This treatment is not a cultural resentment or a reverse of modernity, but an extension of the research perspective to the entire heritage of art related to architectural space, in accordance with the need for interdisciplinarity in academic research.

\section{Space in mural painting \\ and architecture[6]}

It is very difficult to define what space itself is in architecture and art: the material or the result of a creative process. The experience 
of space eludes description and imaging; it is inherently polysensory. Objective, measurable space as a simple result of wall and ceiling structure is not yet an art of architecture. Only conscious, intentional creation of space by architectural and artistic means, which takes into account cultural contexts and psycho-physiology of perception, as well as the aesthetic sensitivity of the recipient, can transfer a building into the field of architectural art.

For many centuries, architecture has been a natural environment for works of art, especially for sculpture and painting. In addition to typical construction measures, architects have extensively used works of art, recognizing their great potential in creating space. Mural painting is of great importance here, to the extent that it is difficult to imagine some works of architecture without painting. Even Leonardo da Vinci appreciated the spatial impact of painting. $\mathrm{He}$ noticed that "the first miracle that manifests in a painting is that it has the appearance of having been detached from the wall or other plane and thus deceives [even] penetrating judgment, although it is not actually separated from the plane of the wall." [7]

Flat mural painting, in its physical matter, controls the internal space of the image, and what is more, it determines and permanently defines the space in front of itself. It has great potential for creating the illusion of space and establishing a formal relationships with architectural elements and their structure. The ability to design paintings in a way that takes into account the amount and characteristics of light, relationships of many elements, the scale and architectural forms, and other properties of space is of fundamental importance. The combination of painting and architecture causes multifaceted spatial multiplications and mutual interactions, creating new spatial and aesthetic values not available for architecture alone. Mural painting, the content of which is space, further enhances the spatial experience in architecture, although at a different level of perception, as it combines real and imagined space. Creating an illusion, playing with spatial impressions involving the interpenetration of reality and illusion - these are the efforts present in art since Hellenistic and Roman antiquity. The Pompeian Villa dei Misteri fully expresses the ancient idiom of a painted interior, which is a testimony to the original need to be surrounded by art, painting, and colour in order to live in an image, in a space of illusion.

\section{The illusion of space in baroque mural painting}

Baroque mural painting based on Euclidean stereometry [8] and the Renaissance conical perspective managed to reach the apogee of the optical illusion of space in an architectural interior. An example is the master fresco by Andrea del Pozzo from 1694's Allegory of the Missionary Work of the Jesuits on the vault of the Sant'Ignazio church in Rome.[9] In the centre of the composition of the fresco, St. Ignatius of Loyola is sitting on the clouds above the real and illusionary painted elements of architecture. He is surrounded by figures of angels and saints floating in the church space against the laws of gravity. Everyone goes into the vast space of the luminous sky, crossing the material structure of the vault.

The viewers standing on the floor may have the impression that they are also participating in this vision. After some analysis carried out in graphic programs, it turned out that Pozzo had visually widened the height of the real barrel vault by three times.[10] The unusual

tion - P. Drozdowicz, Malarstwo $w$ architekturze wspótczesnej - unpublished doctoral dissertation, Uniwersytet Artystyczny w Poznaniu, Poznań 2014, chapter two.

[7] Leonardo da Vinci, Traktat o malarstwie, transl. M. Rzepińska, Wrocław 1961, p. 146.

[8] Most often a variation of Euclidean geometry regarding solids. "A branch of geometry dealing with the study of the spatial properties of geometric figures", <https://sjp.pwn.pl/sjp/stereometria;2576247>, accessed: 3.01.2020.

[9] Designed by Orazio Grassi in the years 1626-1650.

[10] Empire of the Eye: The Magic of Illusion-Sant'Ignazio's Ceiling, o ' $58^{\prime \prime}-1{ }^{\prime} 45^{\prime}$ ', Part 4. 


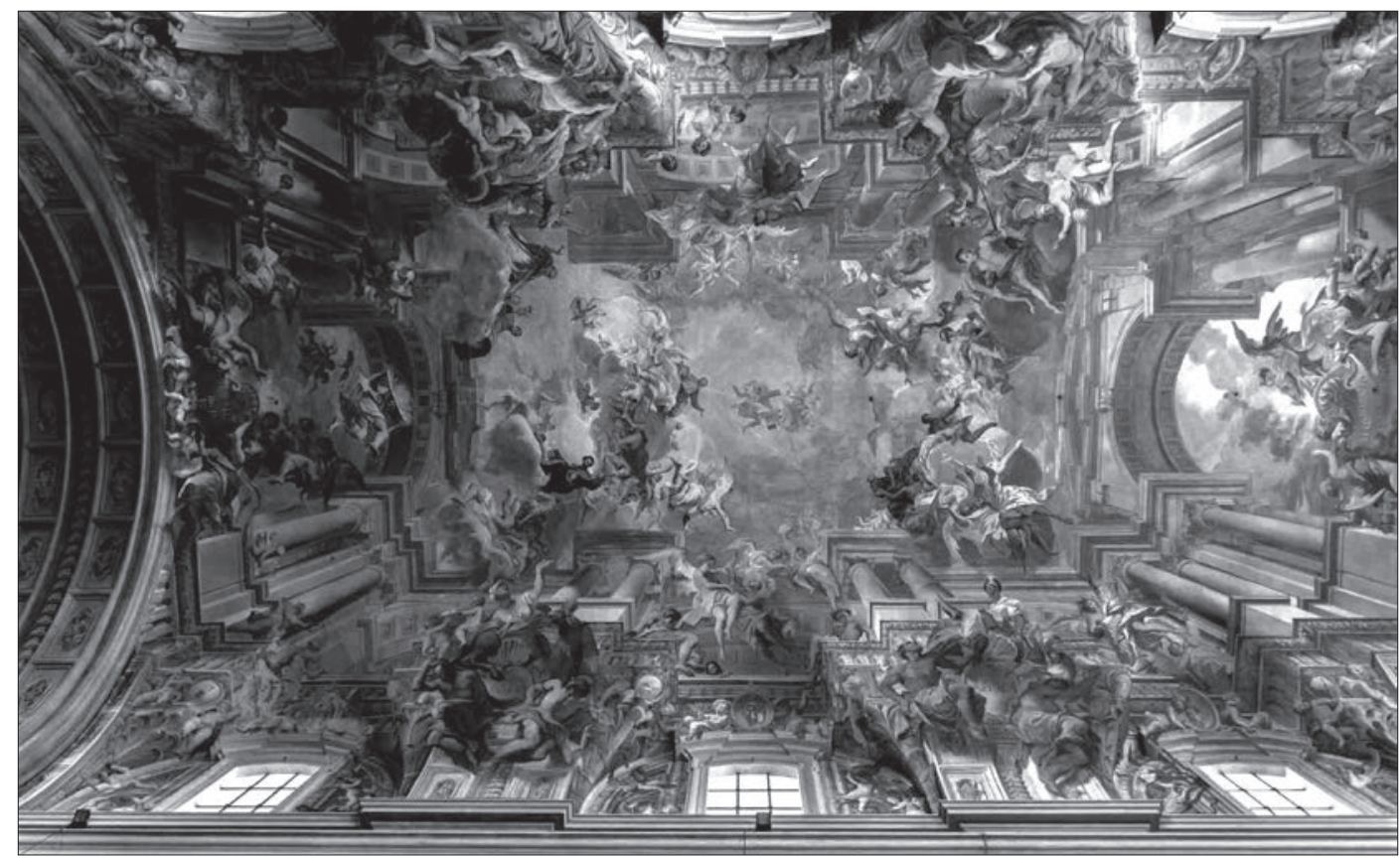

Andrea del Pozzo. Allegory of the Missionary Work of the Jesuits, 1694 r. Phot. Bruce McAdam. Source: $<$ https://pl.wikipedia.org/wiki/Andrea_del_Pozzo\#/media/Plik:Andrea_Pozzo_-_Apoteose_de_Santo_Inacio. jpg>, accessed: 10.01.2020

impressions of the optical illusion of space, difficult to achieve even today with the help of digital media, were obtained not only thanks to non-collinear perspective and quadrature,

$<$ https://www.youtube.com/watch?v=YBaUC4ZBQVs>, accessed 3.01.2020.

[11] The technique of painting the vaults of G.L. Bernini is mentioned in the context of painting analysis in Święta Lipka. A. Stoga, Malowidła Macieja Mejera w Świętej Lipce i ich znaczenie w sztuce polskiej XVIII w., „Komunikaty Mazursko-Warmińskie" 1993, no. 4, p. 523.

[12] Otherwise called the painting perspective, which uses the psychophysiological properties of the perception of warm and cool colours, where warmer colours are perceived as closer and cool as distant, even at similar colour intensity.

[13] Leonardo da Vinci, op.cit., Wrocław 1961.

[14] M. Karpowicz, Działalność artystyczna Michelangela Palloniego w Polsce, Warszawa 1967, p. 135 .

[15] E. Gombrich, Sztuka i złudzenie: o psychologii przedstawienia obrazowego, Warszawa 1981, p. 295. but also, extremely importantly, thanks to the means of painting and the use of the laws of mutual colour interaction. With his great painting skill and baroque stylistics, Pozzo consciously used the achievements of the Renaissance painting masters, Bernini's technique,[11] the colour perspective, $[12]$ and especially the aerial perspective described by Leonardo da Vinci, which consists of gradually brightening and cooling the colours in the further planes of the image.[13] Illusionist painting closely related to the geometry of the architectural space to which it is dedicated is also called three-dimensional painting. [14] The fresco by Andrea Pozzo established close links with the real architecture, sculpture and stucco. "Pozzo attaches importance to the scale of the object, he maintains the proportion between the object and the observer, and ensures that the location of the apparent architecture relative to the observer creates an amazing illusion of depth. Sensations are modified by predictions, guesses and assumptions." [15] 
Mural painting in the context of digital visual media

Based on the interior of the Sant'Ignazio church in Rome, we can analyse the idiom of the space where the illusion impressions reach their apogee. Architectural forms, sculpture, decorations, and painting create a homogeneous, intermedia work of art, a complete work.

There are many analogies between baroque mural painting in architecture and today's VR/ AR multimedia shows. The goal is the same: to dazzle, to enchant the viewers, to put them in a state of illusion of reality. In the past, fresco painting was used; today, it is a pixel image generated with screens or with video mapping projection onto architectural objects, where advanced computer programs calculate projection parameters and adapt the image to the shape of the buildings. Basically, their algorithms are based on the old principles of non-collinear perspective and quadrature.

The perception of painting illusion is possible due to the physical penetration of space by the viewer. Contemporary multimedia projections propose a similar method of perception consisting of the total immersion of the viewer in the image, in the work of art.[16] The effect of immersion in contemporary visual activities seems to be the highest, as if the final degree of image development, which realizes the eternal magical dream to be able to enter the image, the space of the vision, and become a part of its narrative.

Perceiving the image as a magic mirror, or even a wardrobe through which it would be possible to go to another world, has long occurred in culture and it addresses metaphysical needs and a sense of transcendence of reality.[17]

In the case of baroque art, the medium that carries the illusion exists materially on the wall; in the case of VR / AR technology, the image is only a play of light in space that pretends to be real matter. Light determines the final artistic effect of works from both fields. In mural painting, even dim lighting activates both spaces, painting and architecture, as one whole. In
VR / AR projections, however, light is the only material and its absence completely destroys the work. The baroque illusion corresponds to the physical and spiritual nature of man. The existence of the work is not dependent on changes and the development of technology; it does not become outdated and does not go into oblivion, like the PAL, SECAM, U-matic image formats, which no one remembers and can no longer reproduce.

Modern immersion precludes close, physical, haptic contact with digital projection. A painting can be perceived from a distance, but also from a close range, which in each case provides a variety of non-trivial aesthetic experiences. When we get really close to the surface of a fresco, we do not lose the artistic experience, as is the case with digital projections, but we gain new experiences of extraordinary nobility and richness resulting from the physical structure of the painting.

The next difference is in the colour. In mural painting, there is a subtractive colour mixing based on mineral pigments of natural origin. The available colour scale of digital projections is limited to the three colours of the RGB system mixed additively. It is very primitive compared to painting. [18] The forgotten secret of mineral techniques is the crystal structure of

[16] Immersion (Latin: immersio "immersion" from Latin immergere, immersum "to immerse") 1. astr. The entrance of one celestial body in the shadow of another. 2. physics. The phenomenon of improving the quality of observation by optical microscope thanks to filling the space between the preparation and the lens with immersion liquid with an appropriate factor of the refraction of light. As cited in: M. Jarosz et al., Stownik wyrazów obcych, Warszawa 2001.

[17] cf. P. Zawojski, Wewnątrz obrazów. Immersja zamiast iluzji? [in:] Przestrzeń sztuki: obrazy słowa - komentarze, ed. M. Popczyk, Katowice 2005.

[18] The issue of perception and colour mixing developed broadly in terms of art can be found in: A. Mączyńska-Frydryszek, M. Jaskólska-Klaus, T. Maruszewski, Psychofizjologia widzenia, Poznań 1991. 
the pigment and the ground. The very penetration of many transparent layers of paint gives a spatial impression, because light penetrating the structure of the painting surface brings out rich, subtle colour values which, enhanced by reflections caused by the crystalline structure of mineral materials, create a luminous aura of colour, carrying the image to the space in front of itself. This method of painting makes the work emanate glitter and internal light, becoming in the mind of man a space only.[19]

\section{Audiovisual era - conclusions}

Everything indicates that the development of VR and AR digital media technologies will not be stopped, and they already cover areas such as entertainment, business and education.[20] As early as 2000, Piotr Zawojski believed that we are entering the era after "audiovisual", although "audiovisual" probably has not yet reached its apogee. Many observers and commentators critically assess the impact of new electronic technologies on the shape of post-modern cultural mutation, and more broadly on the shape of modern society and civilization, with extreme criticism.[21] The negative effects of excessive, uncoordinated global image digitization are due to modernist delight with technical innovations. The current belief in the future of visual technologies is another instalment of the naive futurism of the early twentieth century and it reveals a technicalist mentality. However, the modern episode of cyber-modernity against the background of many thousands of years of history of mural painting is only a moment. Modern art and the world of VR/AR comes

[19] P. Drozdowicz, op.cit.

[20] For comparison: VR and AR changes in the world on the example of education in: C. Baciu.

The Role of Education in the Era of Virtual Reality and AI, 2016, <https://www.researchgate.net/ publication/295405565_The_Role_of_Education in_the_Era_of_Virtual_Reality_and_AI 10.13140 / RG.2.1.2140.0082>, accessed: 7.01.2020.

[21] P. Zawojski, Elektroniczne obrazoświaty. Między sztuka a technologia, Kielce 2000, pp. 117-118. full circle and slowly arrives at space issues that have been practiced in architecture and mural painting since antiquity. The spatial turn and great interest in space in art confirms the value of classic rules for creating illusionist painting in baroque architecture. Pozzo's fresco analysis shows that mural painting has many features desirable in modern multimedia art and AR activities, such as three-dimensionality, immersion and contextuality, or interactivity and intermediality. There is a need for an alternative in culture for the "after-audiovisual" era. The development of classic art areas, such as mural painting in architecture, could become that alternative.

\section{B I B L I O G R A P H Y}

Baciu C., The Role of Education in the Era of Virtual Reality and AI, Baciu, Ciprian 2016, <https://www. researchgate.net/publication/295405565_The _ Role_of_Education_in_the_Era_of_Virtual_Reality_and_AI 10.13140/RG.2.1.2140.0082>, accessed: 7.01.2020

Drozdowicz P., Malarstwo w architekturze współczesnej - unpublished doctoral dissertation, Uniwersytet Artystyczny w Poznaniu, Poznań 2014

Empire of the Eye: The Magic of Illusion-Sant'Ignazio's Ceiling, p. 4, 0`58' '-1 $45^{\prime}$ ', <https://www.youtube.com/watch? $=$ YBaUC4ZBQVs $>$, accessed: 3.01.2020

Foucault M., O innych przestrzeniach. Heterotopie, transl. M. Żakowski, „Kultura Popularna” 2006, no. 2 (16), pp. 7-14

Gombrich E., Sztuka i złudzenie: o psychologii przedstawienia obrazowego, Warszawa 1981

Karpowicz M., Działalność artystyczna Michelangela Palloniego w Polsce, Warszawa 1967

Krier L., Architektura wspólnoty, Gdańsk 2011

Leonardo da Vinci, Traktat o malarstwie, transl. M. Rzepińska, Wrocław 1961

Mączyńska-Frydryszek A., Jaskólska-Klaus M., Maruszewski T., Psychofizjologia widzenia, Poznań 1991

Stoga A., Malowidła Macieja Mejera w Świętej Lipce $i$ ich znaczenie w sztuce polskiej XVIII w., „Komunikaty Mazursko-Warmińskie" 1993, pp. 519-527

Światek G., Gry sztuki z architektura, Toruń 2013

Zawojski P., Elektroniczne obrazoświaty. Między sztuka a technologia, Kielce 2000

Zawojski P., Wewnątrz obrazów. Immersja zamiast iluzji? [in:] Przestrzeń sztuki: obrazy - słowa - komentarze, ed. M. Popczyk, Katowice 2005 